\title{
BOILERPLATE AND PARTY INTENT
}

\author{
GREGORY KLASS*
}

INTRODUCTION

When courts are called on to determine the terms of a contract, they almost always begin by affirming that "[t]he primary goal in interpreting contracts is to determine and enforce the parties' intent." ${ }^{1}$ But a contract's terms are not only a matter of the parties' intent. Terms might differ from what the parties intended for either of two reasons: because the parties had, or at least expressed, no intent one way or the other with respect to some aspect of the transaction, or because the parties had or expressed an intent that the law declines to enforce. Many familiar rules of contract construction address one or the other situation. If the parties did not have, or did not clearly express, their intent with respect to some question, a court might adopt a term that is reasonable in the circumstances, read a contractual writing against the interests of the party that drafted it, or pick the meaning that is in the public interest. ${ }^{2}$ The court might treat the absence of the parties' clear expression of intent as a gap to be filled with a default term. ${ }^{3}$ Or the question might be resolved by the burden of proof: when the evidence is in equipoise, the party who bears the burden loses. ${ }^{4}$

Other rules of contract construction impose or refuse to enforce terms despite evidence of the parties' contrary intent. Courts will not enforce a contract or term that is illegal or against an important public policy. ${ }^{5}$ The law also includes a raft of mandatory terms. These range from the very general, such as the duty of good faith, "which inheres in all contracts and cannot be disclaimed," to the very specific, such as minimum wage laws, anti-discrimination laws, the mandatory warranty of habitability, and the duties of corporate officers. Clear statement

Copyright (c) 2019 by Gregory Klass.

This Article is also available online at http://lcp.law.duke.edu/.

* Agnes N. Williams Research Professor, Professor of Law, Georgetown University Law Center. I am grateful to John Coyle and Chaim Saiman for helpful comments on an earlier draft of this Article, and to Hannah Beiderwieden for excellent research assistance.

1. Old Kent Bank v. Sobczak, 243 Mich. App. 57, 63 (Mich. Ct. App. 2000).

2. See Restatement (SeCOND) OF ConTracts $\$ \S 204,206,207$ (AM. LAW InSt. 1981) [hereinafter SECOND RESTATEMENT].

3. See, e.g., U.C.C. § 1-302(a) (AM. LAW INST. \& UNIF. LAW COMM'N 2018) (describing most of the provisions of the Code as default terms).

4. This occurred most famously in Frigaliment Importing Co. v. B.N.S. Int'l Sales Corp., 190 F. Supp. 116, 121 (S.D.N.Y. 1960) ("[P]laintiff has the burden of showing that 'chicken' was used in the narrower rather than in the broader sense, and this it has not sustained.").

5. See SECOND RESTATEMENT $§ 178$ (describing the factors courts should consider in weighing the interest in enforcing terms against the interest in promulgating policy).

6. Alta Vista Props., LLC v. Mauer Vision Ctr., 855 N.W.2d 722, 730 (Iowa 2014). 
rules can prevent parties who do not know the magic words from getting the terms they intend. ${ }^{7}$ And by excluding evidence of the parties' actual intent, formalist rules of construction like the plain meaning and parol evidence rules can sometimes bind parties to terms contrary to their intent. It might be that the primary goal in contract interpretation is to determine and enforce the parties' intent. But that is not the only goal in contract construction.

Contractual boilerplate is subject to all of the above rules, but also raises issues of its own. When applied to contractual writings, "boilerplate" is used in two distinct senses. Sometimes it refers to clauses that almost always appear in contractual writings, or contractual writings of a certain type, that are unlikely to be negotiated or even read by the principals, but that might be altered by the lawyers-for style or for substance. In negotiating a commercial lease, for example, the lawyers might or might not discuss and change the wording of an integration clause, a severability clause, a notice provision, or a no-waiver clause, treating those terms as mere boilerplate that need not be brought to the principals' attention and might be left untouched. Call this "soft boilerplate."

This Article focuses on the other sense of "boilerplate": language that is not open to negotiation or alteration. Such "hard boilerplate" corresponds to the original sense of the term: the words in some contractual writings are as fixed and unchanging as the thick steel plating on steam boilers. The most commonlydiscussed type of hard boilerplate is the contract of adhesion: a written agreement drafted by one party and given to others on a take-it-or-leave-it basis. ${ }^{8}$ Other types include contractual writings drafted by third parties, such as industry associations, that are expected to be used without modification, and clauses that are legally required in certain types of contracts, such as the consumer credit notice provisions that the Federal Trade Commission mandates in consumer contracts. ${ }^{9}$ From this point forward, the reader should read "boilerplate" to mean hard boilerplate.

Boilerplate can give rise to discontinuities between the parties' intent and the legal terms they are bound to for either of the two reasons identified above: because the parties do not have, or have not expressed, an intent one way or another with respect to a term, or because one or another rule prevents the parties' intent from being effective.

The more familiar discontinuities are those of the first type. Boilerplate often addresses issues that are not salient to one or both parties, who are therefore less likely to read and understand it. Such parties do not, at least in one sense, intend what the boilerplate says. This is certainly true of contracts of adhesion, which

7. See John F. Coyle, Interpreting Forum Selection Clauses, 104 IOWA L. REV. 1791, 1803-18 (2019) (describing clear statement rules for the scope of forum selection clauses); John F. Coyle, The Cannons of Construction for Choice-of-Law Clauses, 92 WASH. L. REV. 631, 666-80 (2017) (describing clear statement rules for the scope of choice-of-law clauses).

8. See Todd D. Rakoff, Contracts of Adhesion: An Essay in Reconstruction, 96 HARV. L. Rev. 1173, 1177 (1983) (listing seven distinctive characteristics of adhesive contracts).

9. 16 C.F.R. $§ 433.2$ (2019). 
non-drafting parties often do not take the time to read. And it can be true of third-party drafted forms. The much-discussed example of pari passu clauses in sovereign debt contracts has shown in addition that even bespoke agreements amongst highly sophisticated parties might contain soft boilerplate clauses to which the parties attach no meaning..$^{10}$ John Coyle and Mark Weidemaier have recently argued that the same is true of less arcane and more widespread provisions, such as choice-of-law and arbitration clauses. ${ }^{11}$

The experience with pari passu clauses in sovereign debt instruments has prompted scholars to rethink how courts should construe contractual "black holes"12 - boilerplate that has neither a conventional meaning nor a meaning for the parties. ${ }^{13}$ My own intuition, which I will not fully defend here, is that courts are not the institutions best equipped to solve so-called black hole problems, or the related phenomenon of linguistic drift in boilerplate terms. Everyone agrees, for example, that issuers of sovereign debt had a range of tools at their disposal to address the risk pari passu clauses posed once that risk was exposed-ranging from redrafting individual offerings to industry-wide reform. If those highly sophisticated parties and their lawyers were less responsive to the danger than traditional models suggest, it does not follow that it is courts' job to fix the problem. The same goes for contracts in which boilerplate language has shifted over time due to lawyerly tweaks. There are familiar costs to courts doing the parties' work for them. Most importantly, sophisticated parties are arguably the least cost avoiders of any risks imposed by meaningless contract language. Leaving those risks on those sophisticated parties generates the right incentives. ${ }^{14}$

Be that as it may, this Article focuses on discontinuities between contract boilerplate and party intent of the second type: instances in which a court, because the term at issue appears in boilerplate, declines to take into account evidence of the parties' intent. The existence of contract terms contrary to party intent is a general phenomenon. But sometimes the discontinuity results from those terms' appearance in contract boilerplate. This Article investigates those discontinuities.

10. See Elliott Assocs., L.P., General Docket No. 2000/QR/92, Cour d'Appel [CA] [Court of Appeal] Bruxelles, 8éme ch., Sept. 26, 2000 (Belg.); William W. Bratton, Pari Passu and a Distressed Sovereign's Rational Choices, 53 EMORY L.J. 823, 823-25 (2004) (describing the facts and ruling); W. Mark C. Weidemaier \& Anna Gelpern, Injunctions in Sovereign Debt Litigation, 31 YALE J. ON REG. 189, 194-98 (2014).

11. See generally John F. Coyle \& W. Mark C. Weidemaier, Interpreting Contracts Without Context, 67 AM. U. L. REV. 1673 (2018).

12. See generally Stephen J. Choi, Mitu Gulati, \& Robert E. Scott, The Black Hole Problem in Commercial Boilerplate, 67 DUKE L.J. 1 (2017).

13. See, e.g., Stephen J. Choi \& Mitu Gulati, Contract as Statute, 104 MiCH. L. REV. 1129, 1159-72 (2006); Choi et al., supra note 12, at 66-70; Coyle \& Weidemaier, supra note 11, at 1682.

14. I am therefore sympathetic to Anna Gelpern's suggestion, in effect, that sovereign debt issuers just get their act together and, like other industries have, organize the centralized production of standard terms. Anna Gelpern, The Importance of Being Standard, EuropeAn CENT. BANK 2016 ANN. LEGAL DEP’T CONF. PROC. (2017), https://ssrn.com/abstract=2963333 [https://perma.cc/B8F6-TB2H]. 
This Article does not develop a grand theory of boilerplate contrary to party intent, but seeks only to map the terrain. It identifies and discusses doctrines and judicial opinions that illustrate various reasons courts sometimes limit evidence of party intent because a term appears in boilerplate. Part II sets the stage by examining three generally applicable reasons courts sometimes exclude evidence of party intent: plain meaning rules, the parol evidence rule, and the use of formalities. Although these rules apply to many different types of contractual writings, each finds special application to contract boilerplate. Part III discusses judicial construction of mandatory clauses: language that parties are required by law to include in their agreements. In these instances, there are often good reasons to interpret the clause in line with the government's reading of it, even if the parties have a different understanding of what they agreed to. Part IV examines standard form agreements drafted by private entities, such as industry associations or private publishers. Standard forms are often properly treated no differently from other contractual writings. But when they are used in markets that significantly benefit from uniform terms, it can make sense to construe them in ways that depart from individual parties' intent. Part IV identifies various ways such uniformity might be achieved. Part V discusses contracts of adhesion, giving special attention to section 211(2) of the Restatement (Second) of Contracts. This often overlooked provision appears to instruct courts to read adhesive contracts, and perhaps boilerplate generally, with limited regard to the parties' intent. It has recently found new application in consumer class actions to establish commonality of claims. Part VI concludes.

II

\section{CONTRACT FORMALISM AND BOILERPLATE}

To repeat, there are many reasons why the terms of a contract, whether or not the contract is created using boilerplate, might diverge from the parties' intent. These include the various forms of formalism that are applied to the construction of contractual writings. This Part considers three varieties of formalism in the law of contract-plain meaning rules, the parol evidence rule, and the use of formalities - and the application of each to contract boilerplate. Each type sometimes excludes from the construction of a contractual writing evidence of the parties' actual agreement or intent. But they do so in different ways, and to different ends. And they stand in various relationships to contract boilerplate.

Plain meaning rules restrict the evidence that goes into the interpretation of certain types of contractual writings. The New York Court of Appeals has formulated New York's plain meaning rule as follows:

[W] hen parties set down their agreement in a clear, complete document, their writing should as a rule be enforced according to its terms. Evidence outside the four corners 
of the document as to what was really intended but unstated or misstated is generally inadmissible to add to or vary the writing. ${ }^{15}$

A writing's plain meaning is that meaning that can be gleaned from the writing itself, together perhaps with a dictionary and the interpreter's background understanding of the world and the transaction. ${ }^{16}$ Because even sophisticated parties sometimes fail to capture in writing all the nuances of their actual agreement, plain meaning rules sometimes result in discontinuities between a contract's terms and the parties' intent-namely, when the latter might have been proven with extrinsic evidence.

The generic arguments for and against plain meaning rules are at this point familiar. And many of the same considerations-such as greater predictability, reduced costs of litigation, increased costs of drafting, and errors that result from excluding extrinsic evidence-apply to contractual boilerplate. There are, however, two reasons to think that plain meaning rules might be especially appropriate in the interpretation of boilerplate. First, one might argue that a party who has not drafted the agreement should be entitled to rely on its plain meaning - that is, on the meaning that appears on the document's face. This is especially so in transactions in which boilerplate terms are not discussed, so that any extrinsic evidence as to the term's meaning will come from outside the transaction.

Second, as Parts IV and V discuss, boilerplate is sometimes employed to achieve uniformity of terms, whether in an entire market or in transactions with a particular seller. By cutting off evidence from individual transactions and arguably cabining judicial discretion, plain meaning rules can help secure the uniform interpretation of boilerplate language. To the extent that such uniformity has social value, there is special reason to interpret some boilerplate according to its plain meaning.

The application of the parol evidence rule to contract boilerplate might also be distinctive. The parol evidence rule provides that an integrated writing is the sole legally-operative document or act in a transaction-either with respect to the terms contained the writing, if it is partially integrated, or with respect to the transaction as a whole, if the writing is completely integrated. Although the parties' other communications might sometimes be used to explain the writing's meaning, they cannot therefore be used to contradict or, if the integration is complete, supplement it. Applications of the rule can operate to exclude evidence from outside the writing tending to show that the parties in fact intended or agreed to terms other than those contained in it.

15. W.W.W. Assocs., Inc. v. Giancontieri, 77 N.Y.2d 157, 162 (1990). See also R/S Assocs. v. N.Y. Job Dev. Auth., 98 N.Y.2d 29, 32 (2002).

16. See Alan Schwartz \& Robert E. Scott, Contract Theory and the Limits of Contract Law, 113 YALE L.J. 541, 572 (2003) (describing the minimal evidentiary base for interpretation as "the parties' contract, a narrative concerning whether the parties performed the obligations that the contract appears to require, a standard English language dictionary, and the interpreter's experience and understanding of the world"). 
Today, Anglo-American courts generally treat the integration of contractual writings as a matter of party agreement. A writing is integrated if and only if the parties intend it to be final statement of some or all of the terms of a contract between them. ${ }^{17}$ In other words, a writing is integrated if and only if the court concludes that the parties have agreed that other evidence of their intent, including prior agreements, is not legally operative.

Integration was not always, and is not everywhere, a matter of party intent. As Wigmore observes, some writings are subject to "compulsory integration," where "the law insists, independently of the parties' choice, that the transaction be embodied in a single document, and when this is done, the same jural consequences attach." 18 This is where boilerplate comes in. There is some authority for the proposition that boilerplate-unlike other contractual writings - is subject to compulsory integration, or at least to default integration. Consider Judge Winter's oft-quoted statement in Sharon Steel Corp. v. Chase Manhattan Bank, N.A. concerning standard terms in a debenture:

Boilerplate provisions are ... not the consequence of the relationship of particular borrowers and lenders and do not depend upon particularized intentions of the parties to an indenture. There are no adjudicative facts relating to the parties to the litigation for a jury to find and the meaning of boilerplate provisions is, therefore, a matter of law rather than fact. ${ }^{19}$

Along the same lines, section 211(1) of the Second Restatement provides that, except in limited circumstances,

[w] here a party to an agreement signs or otherwise manifests assent to a writing and has reason to believe that like writings are regularly used to embody terms of agreements of the same type, he adopts the writing as an integrated agreement with respect to the terms included in the writing. ${ }^{20}$

This suggests an integration rule that turns not on evidence of the parties' intent to integrate, but on the fact that the writing is adhesive boilerplate. It might be that at least some boilerplate terms are integrated by operation of law, as distinguished from the parties' agreement. Although this Article does not discuss automatic integration further, it is worth keeping in mind. ${ }^{21}$

17. See, e.g., 2 SAMuel Williston, The LaW Of CONTRACTS $\S 633$, at 1225 (1st ed. 1924) ("The parol evidence rule does not apply to every contract of which there is written evidence, but only applies where the parties to an agreement reduce it to writing, and agree or intend that that writing shall be their agreement.") (internal quotation marks omitted) [hereinafter WILLISTON FIRST EDITION]; Arthur L. Corbin, The Parol Evidence Rule, 53 YALE L.J. 603, 603 (1944) (stating that a writing is integrated when the parties "have both assented [to it] as the complete and accurate integration of that contract"). For more on this point, see generally Gregory Klass, Parol Evidence Rules and the Mechanics of Choice, 20 THEORETICAL INQUIRIES L. 457 (2019).

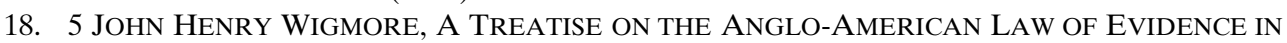
TRIALS AT COMMON LAW, $\$ 2450$, at 348 (2d ed. 1923). Wigmore goes on to explain that "[t] of compulsory integration are few. At common law the only instances appear to be those of judicial records, corporate records, and negotiable instruments. By statute have been added testaments and a few miscellaneous documents." Id. (emphasis added).

19. 691 F.2d 1039, 1048 (2d Cir. 1982).

20. SECOND RESTATEMENT § 211(1).

21. I advocate a version of such a rule for adhesive consumer contracts in Parol Evidence Rules and the Mechanics of Choice, supra note 17. 
Yet a third type of formalism in contract law is the use of formalities. The relationship between formalities and contractual boilerplate is especially complex. A formality is a linguistic or other act that affects a legal change solely by virtue of its form, as distinguished from its meaning. The most well-known contract formality is the private seal. ${ }^{22}$ When the seal was in full force, placing a seal on a writing rendered the writing legally effective upon delivery. ${ }^{23}$ There was no need for a separate inquiry into the writing's meaning or the sealer's intent. Thus Williston reported with respect to the seal in the first edition of his treatise: "If the forms are observed, the obligation is binding. ... [A]t common law mutual assent or any intention on the part of either obligor or obligee was entirely unnecessary." ${ }^{24}$

Although legislation has limited the seal's legal effectiveness in most U.S. jurisdictions, formalities have not disappeared from the law of contract. Article Two of the Uniform Commercial Code (the Code) renders the seal inoperative in contracts for the sale of goods, ${ }^{25}$ and generally instructs courts to take a context-inclusive approach when interpreting the parties' agreement. ${ }^{26}$ But the Code does not do away with formalities altogether. It attaches, for example, to the terms "F.O.B.," "F.A.S.," "C.I.F.," and "C. \& F." precise legal effects on a seller's shipment obligations. ${ }^{27}$ Similarly, section 2-316 effectively establishes "as is" and "with all faults" as formalities by providing that use of either operates without further inquiry to exclude all implied warranties. ${ }^{28}$

Unlike the old rule for the seal, these Code formalities do not fully displace an inquiry into the parties' intent. "As is" and "with all faults" operate to exclude all implied warranties "[u]nless the circumstances indicate otherwise," 29 and each of the provisions for the various shipment terms - "F.O.B.," "F.A.S.," etc. - is qualified with the words, "unless otherwise agreed." 30 But the terms shift the burden to the litigant who wishes to argue that the parties intended something

22. See Eric Mills Holmes, Stature and Status of a Promise Under Seal as a Legal Formality, 29 WILLAMETTE L. REV. 617 (1993) (noting that the private seal is still operative in many U.S. jurisdictions, although its legal effects have changed over time).

23. SECOND RESTATEMENT § 95(1).

24. 1 WILLISTON FIRST EDITION $§ 205$, at 412.

25. U.C.C. § 2-203 (AM. LAW INST. \& UNIF. LAW COMM’N 2018).

26. See, e.g., id. § 2-204.

27. Id. $\S \S 2-319-20$. The since-withdrawn 2003 Amendments to Article Two would have eliminated these provisions "because they are inconsistent with modern commercial practices." U.C.C. § 2-319 (AM. LAW INST. \& UNIF. LAW COMM'N 2004).

28. U.C.C. § 2-316(3)(a) (AM. LAW INST. \& UNIF. LAW COMM'N 2018). Although the rule is written as if the phrases are mere examples, in practice it establishes these ordinary-language terms as sufficient to achieve the relevant legal effect. See, e.g., Meyer v. Alex Lyon \& Son Sales Managers \& Auctioneers, Inc., 889 N.Y.S.2d 166, 168 (N.Y. App. Div. 2009) (holding that the defendants' "as is" clause disclaimed all implied warranties without further inquiry); Prudential Ins. Co. of America v. Jefferson Assocs, Ltd., 896 S.W.2d 156, 161 (Tex. 1995) (same); Welwood v. Cypress Creek Estates, Inc., 205 S.W.3d 722, 726 (Tex. App.-Dallas 2006) (same); Warner v. Design and Build Homes, Inc., 114 P.3d 664 (Wash. Ct. App. Div. 2 2005) (same).

29. U.C.C. § 2-316(3)(a) (AM. LAW INST. \& UNIF. LAW COMM’N 2018).

30. Id. §2-319-25. 
other than the formality's standard legal effect. ${ }^{31}$ Even with the escape hatches, these formalities can therefore lead to outcomes that do not correspond to the parties' intent.

Lon Fuller observed that form "offers channels for the legally effective expression of intention." 32 Contract formalities are typically designed to empower parties to get the terms they want. Formalities have two familiar advantages here. First, they reduce transaction costs, both at the time of formation and should the agreement be adjudicated. Rather than drafting a bespoke clause to ensure that a possible third-party adjudicator will recognize their intent, parties can use an off-the-rack formality. And formalities save litigation costs by obviating complex ex post inquiries into meaning and intent. Second, the effects of a formality are more certain and predictable than those of bespoke contract language. Litigating the meaning of the parties' words and actions is not only expensive, but also unpredictable and sometimes error-prone. Because a formality is effective by virtue of its form alone, it enhances parties' ability to secure the terms they want. But of course, formalities can also go awry. If one or both parties do not understand that they are using a formality, or do not understand its legal effect, its legal consequences might not match the parties' intent or expectations.

All this is relevant because sometimes contract boilerplate is best understood as a judicially-created formality. For example, for several centuries the Lloyd's marine insurance contract was a pre-printed form used in transactions between owners and underwriters. ${ }^{33}$ The policy's Adventures and Perils Clause described the covered risks as follows:

Touching the Adventures and Perils which we the Assurers are contented to bear and do take upon us in this Voyage, they are, of the Seas, Men-of-War, Fire, Enemies, Pirates, Rovers, Thieves, Jettisons, Letters of Mart and Counter-mart, Surprisals, Takings at Sea, Arrests, Restraints and Detainments of all Kings, Princes, and People, of what Nation, Condition or Quality soever, Barratry of the Master and Mariners, and of all other Perils, Losses and Misfortunes that have or shall come to the Hurt, Detriment, or Damage of the said Goods and Merchandises and Ship, \&c., or any Part thereof. ${ }^{34}$

In his 1914 treatise, Sir Douglas Owen observed of the clause:

31. The modern rules for the seal also render its legal effects defeasible. Thus the Second Restatement specifies that "[t]he adoption of a seal may be shown or negated by any relevant evidence as to the intention manifested by the promisor." SECOND RESTATEMENT $\S 98$, cmt. a. See also id. $\S 96$ cmt. b ("[A] document which bears a seal does not establish its own authenticity. Evidence of extrinsic circumstances may be necessary to show that a promisor affixed or adopted a seal and that the document was delivered.").

32. Lon L. Fuller, Consideration and Form, 41 Colum. L. REV. 799, 801 (1941).

33. For a detailed history of the Lloyd's form and its many peculiarities, see CHARLES WRIGHT \& C. ERNEST FAYLE, A HISTORY OF LLOYD's: FROM THE FOUNDING OF LLOYD'S COFFEE HOUSE TO THE PRESENT DAY, 126-57 (1928). I am grateful to Jim Oldham for bringing this example to my attention. See James Oldham, Insurance Litigation Involving the Zong and other British Slave Ships, 1780-1807, 28 J. LEGAL HIST. 299, 300 (2007) (depicting the manner in which the standard Lloyd's marine insurance policy was understood by ship owners and merchants in the British slave trade).

34. Douglas Owen, OCEAn Trade AND ShIPPING, 156 (1914) (describing the Adventures and Perils Clause) (error in original). 
It is an ancient and incoherent document, occasionally the subject of judicial remarks in the highest degree uncomplimentary. But nobody minds this or dreams of altering the ancient form, nor, one may imagine, is it ever likely to be altered. Insurance experts know-or very often know-exactly what it means, and with generations of legal interpretations hanging almost to every word, and almost certainly to every sentence, in it, it would be highly dangerous to tamper with it. ${ }^{35}$

The Adventures and Perils Clause is best understood as a judicially-created formality. Its application did not require interpretation of the words in it, much less of the parties' intent in using them. In fact, such interpretation might lead the reader astray as to its legal effect. Instead, the boilerplate's legal effect lay entirely in the body of caselaw applying the clause -in earlier judicial opinions construing it. ${ }^{36}$

Scholars have occasionally suggested that the judicial construction of contract language might be usefully employed to create new formalities. In an influential 1985 article, Charles Goetz and Robert Scott call formalities "invocations" 37 and suggest that "[s]killful use of the [plain-meaning] presumption by courts will, over time, increase the supply of officially recognized invocations and other express conventions." ${ }^{38}$ Marcel Kahan and Michael Klausner argue along similar lines that "[i]nterpretation of standard terms should be treated like the interpretation of laws: Judges, not juries, should interpret them, and their interpretation should have precedential value." ${ }^{39}$ More recently and more radically, Ian Ayres has suggested that "[i]n deciding interpretation disputes, and in fact in deciding any contractual issue concerning defaults, judges should presumptively provide in their decisions contractual language that would allow future contractors to achieve the results desired by the losing party." ${ }^{40}$ The suggestion seems to be that such dicta would generate new formalities: new fixed boilerplate language parties could employ to get the legal outcomes they desire.

The discussion below argues that it sometimes makes sense for courts to give special deference to prior judicial construction of the same boilerplate language

35. Id. at 155. See also WRIGHT \& FAYLE, supra note 33, at 131 (observing that "[t]he merits of Lloyd's policy are, in fact, quite independent of its drafting").

36. See id.

37. Charles J. Goetz \& Robert E. Scott, The Limits of Expanded Choice: An Analysis of the Interactions Between Express and Implied Contract Terms, 73 CALIF. L. REV. 261, 282 (1985) (defining "invocations" to mean "terms that, once deliberately called upon, have a legally circumscribed meaning that will be heavily-perhaps even irrebuttably-presumed.").

38. Id. at 316. See also id. at 288 ("A . . . critically important benefit of standardized formulations is the reliability that results from the process of 'recognition.' A term is recognized when it is identified through adjudication or statutory interpretation and blessed with an official meaning ... . Contract interpretation therefore serves to determine and announce relatively reliable definitions of contractual formulations that are protected by official acceptance.").

39. Marcel Kahan \& Michael Klausner, Standardization and Innovation in Corporate Contracting (Or "The Economics of Boilerplate"), 83 VA. L. REV. 713, 765 (1997). See also Michael Klausner, Corporations, Corporate Law, and Networks of Contracts, 81 VA. L. REV. 757, 776 (1995) (arguing that network benefits accrue from the fact that "[a] judicial opinion that interprets one corporation's contract term in effect embeds that interpretation in the contracts of all firms that use the same term").

40. Ian Ayres, Regulating Opt-Out: An Economic Theory of Altering Rules, 121 YALE L.J. 2032, 2055 (2012). 
appearing in a separate transaction. But those instances are rare, and, importantly, the goal is not to empower parties to get the terms they want, as one might expect.

To see why, consider how different the legal environment in which the Lloyd's standard marine insurance policy evolved was from today's. Most transactions were consummated literally across the table in a large hall known simply as "The Room." ${ }_{11}$ Parties to the policy-owners and underwriters-were all highly sophisticated repeat players. The policy itself was subject to interpretation by a single appellate court, the King's Bench, meaning there were no splits amongst jurisdictions. And when deciding cases, the King's Bench regularly called on expert judicial advisors and empaneled special juries comprised of industry members. ${ }^{42}$ The body of caselaw that developed around the Adventures and Perils clause was therefore especially likely to meet the needs of the industry and to be understood by the form's users.

Today the vast majority of contracts inhabit a very different environment. In the U.S., standardized contractual language can be subject to the law of over fifty jurisdictions. ${ }^{43}$ Kahan and Klausner argue that the interpretation of standard terms "should have precedential value." 44 But it is difficult in a federal system to generate broadly binding judicial constructions of boilerplate language. A Kansas district court's construction of contractual language under Kansas law is not binding even on another district court sitting in Kansas and applying the same law, ${ }^{45}$ much less on courts sitting elsewhere and applying the law of other states. And there are often good reasons for one court not to defer to another's construction of the same language in a contractual agreement between different parties. What matters in most contract cases is the apparent intent of these parties to this contract. The correct interpretation of a contractual agreement is therefore in most cases properly understood as a question of fact, not law: based on the permissible evidence, what did these parties actually or apparently intend? ${ }^{46}$

41. See OWEN, supra note 34, at 116-20 (describing the process of marine underwriting at Lloyd's).

42. See James Oldham, The Law of Negligence as Reported in The Times, 1785-1820, 36 LAW \& Hist. REV. 383, 396 (2018) (discussing common law courts' use of sailors on special juries and retired sea captains as judicial advisors in maritime cases between 1785 and 1820, as well as counsel's familiarity with seagoing rules); James Oldham, The Origins of the Special Jury, 50 U. CHI. L. REV. 137, 173-75 (1983) (discussing the longstanding use of merchants on special juries in cases before the King's Bench).

43. Jeffrey Golden, a principal drafter of the International Swaps and Derivatives Association's (ISDA) Master Agreement, which is discussed in Part IV, reports that the ISDA Master gives users a choice between the law of only two jurisdictions in order to ensure consistency in judicial interpretation. "At the time that the ISDA Master was first published, the drafters felt that there was likely to be little variation in the way that an English or a New York court would construe the terms of the agreement." Jeffrey Golden, Interpreting ISDA Terms: When Market Practice is Relevant, as of When is it Relevant?, 9 CAP. MKTS. L.J. 299, 304-05 (2014). Golden also observes, however, that in recent years the interpretive approaches of courts in the two jurisdictions have diverged. Id. at 305.

44. Kahan \& Klausner, supra note 39, at 765.

45. 18 J. MoOre eT AL., MOORE’s Federal PRACTICE $§ 134.02(1)(d)$, at 134-26 (3d ed. 2011) (“A decision of a federal district court judge is not binding precedent in either a different judicial district, the same judicial district, or even upon the same judge in a different case.").

46. For a cogent explanation, see 3 ARTHUR LINTON CORBIN, CORBIN ON CONTRACTS: A 
Although one court's interpretation of contract language might have persuasive power in a future case, it does not typically have the effect of stare decisis. ${ }^{47} \mathrm{In}$ such a legal system, the generation of widespread binding precedent might take decades to produce.

Moreover, a boilerplate formality empowers parties to get the terms they want only if parties know both (a) that courts attach a specific legal effect to those words - that they not simply another clause - and (b) what that effect is - which might differ from the words' apparent or plain meaning. Because boilerplate formalities originate as ordinary contract terms, they are not always easy to recognize as having a special legal effect-distinguishing them, for example, from the seal or terms like "F.O.B" or "F.A.S." And because courts do not always construe boilerplate in accordance with its plain meaning, the legal effect of a boilerplate formality might not appear on its face. It is important that users of the Lloyds' marine insurance policy were highly sophisticated repeat players.

Michelle Boardman has argued that in the insurance market, contra proferentem, together with judicial deference to earlier constructions of standard contract language, has rendered insurance boilerplate "a private conversation between drafters and the courts" that consumers are not equipped to understand. ${ }^{48}$ And the barriers to understanding boilerplate formalities do not apply only to consumers. Ayres does not explain, for example, how the transactional lawyers who draft contractual agreements will learn of a judicial opinion that "drop[s] a footnote identifying what language would be sufficient." 49 One might guess that in all but the most specialized fields many will remain unaware of such judicial advice.

None of this is to say that there exist no circumstances in which judicial construction can profitably be used to give boilerplate a fixed legal effect. And as will be discussed below, U.S. courts have occasionally said this is precisely what should happen in certain types of cases. But if the goal is to "empower ... future parties" $" 50$ through the creation of new formalities, it is not obvious that judiciallycreated boilerplate formalities are the correct method.

COMPREHENSIVE TREATISE ON THE RULES OF CONTRACT LAW § 554, at 218-27 (1951). This is not, of course, to say that courts cannot develop rules of construction, such as clear statement rules, that call for special forms of expression. See Ayres, supra note 40, passim (discussing various types of altering rules).

47. See, e.g., S. Hampton Co. v. Stinnes Corp., 733 F.2d 1108, 1115 n.5 (5th Cir. 1984) ("[T]he determination of ambiguity, like other fact questions, will sometimes be a question to be answered by the judge and not the jury ... The determination, however, does not become imbued with stare decisis effect just because a judge made it.").

48. Michelle E. Boardman, Contra Proferentem: The Allure of Ambiguous Boilerplate, $104 \mathrm{MICH}$.

L. REV. 1105 (2006).

49. Ayres, supra note 40, at 2056.

50. Ayres, supra note 40, at 2055. 


\section{III}

\section{MANDATORY ClAUSES}

Having made these general observations, I now turn to examples of judicial approaches to boilerplate that can produce terms contrary to those intended by the parties. This Part considers the construction of mandatory clauses. A mandatory term is a term that the law imposes on contracting parties whether they want it or not. Mandatory terms are familiar in the scholarly literature. ${ }^{51}$ Much less discussed are mandatory clauses: boilerplate language that the law requires be included in some contractual writings. ${ }^{52}$

A helpful example, and interesting set of judicial opinions, can be found in the First Circuit's 2013 en banc ruling in Kolbe v. BAC Home Loans Servicing, $L P{ }^{53}$ At issue was the legal effect of uniform covenants that the Federal Housing Administration (FHA) and the Department of Housing and Urban Development (HUD) mandate be included in federally-insured mortgages. Paragraph Four of the covenants requires that the borrower insure both (a) "against any hazards, causalities, and contingencies, including fire, for which Lender requires insurance" and (b) "against loss by flood to the extent required by the Secretary [of HUD]." ${ }^{54}$ This wording has given rise to a considerable amount of litigation on whether Paragraph Four sets a floor or a ceiling on the amount of flood insurance a bank may require the borrower to carry. Banks argue that it sets a floor, on the theory that insurance against "hazards" includes flood insurance (floods being hazards), and therefore the first quoted clause authorizes lenders to require more flood insurance than that required by the Secretary. Borrowers argue that the clause sets a ceiling, based on the theory that hazard insurance commonly does not cover floods, which means that the second clause controls and the federally-set amount is the only flood insurance that may be required.

In Kolbe, the defendant-creditor had purchased the mortgage at issue from the originating bank. This fact permitted the borrower to argue inter alia that no matter how the defendant understood Paragraph Four, the original parties to contract, whose understandings controlled, both understood it to set a ceiling on

51. For a recent attempt at a systematic theory of mandatory terms, see Eyal Zamir \& Ian Ayres, Mandatory Rules, Hebrew U. JeRUSAlem Legal StUd. ReS. PAPER SERIES No. 19-12, 1 (2019), https://ssrn.com/abstract=3420179 [https://perma.cc/CPZ2-ZDEN].

52. But see id. at 38-43 (discussing regulation of a contract's wording).

53. 738 F.3d 432 (1st Cir. 2013). For other decision addressing the interpretation of mandatory clauses, see $i d$. at 443 (discussing cases); Aguiar v. Generali Assicurazioni Ins. Co., 715 N.E.2d 1046, 1048 (Mass. App. 1999); Moritz v. Farm Bureau Mut. Ins. Co., 434 N.W.2d 624, 626 (Iowa 1989).

54. The complete clause reads:

4. Fire, Flood and Other Hazard Insurance. Borrower shall insure all improvements on the Property, whether now in existence or subsequently erected, against any hazards, casualties, and contingencies, including fire, for which Lender requires insurance. This insurance shall be maintained in the amounts and for the periods that Lender requires. Borrower shall also insure all improvements on the Property, whether now in existence or subsequently erected, against loss by flood to the extent required by the Secretary.

Requirements for Single Mortgage Instruments, 53 Fed. Reg. 25434-01, 25438 (July 6, 1988). 
how much flood insurance the lender could require..$^{55}$ And in fact, the originating bank had never required more flood insurance than the HUD mandated minimum. The district court rejected the borrower's argument and dismissed the complaint on the theory that Paragraph Four unambiguously set a floor not a ceiling. ${ }^{56}$ A divided three-judge panel of the First Circuit reversed, with the majority finding Paragraph Four ambiguous and holding that the plaintiff should therefore be permitted to introduce extrinsic evidence of its meaning. ${ }^{57}$ The en banc court was evenly divided, thereby affirming the district court's ruling, as the panel's opinion had been vacated upon granting the motion for reconsideration. ${ }^{58}$

As Judge Lipez argued in an opinion disagreeing with the outcome, the district court's dismissal of the complaint effectively denied the plaintiff borrower any chance to introduce evidence of the parties' actual intent with respect to their agreement. ${ }^{59}$ So why was the plaintiff not given that chance? Chief Judge Lynch wrote the lead opinion defending that outcome. Judge Lynch made several arguments, including an appeal to section 211(2) of the Second Restatement, which he read for the principle that "[e]xtrinsic evidence of the parties' unique intentions regarding a uniform clause is generally uninformative because unlike individually tailored contracts, uniform clauses do not derive from the negotiations of the specific parties to a contract." ${ }^{\prime 0}$ Part V considers the import of $\S 211(2)$. More relevant for present purposes is Judge Lynch's separate appeal to the general principle that " $[\mathrm{w}]$ hen dealing with uniform contract language imposed by the United States, it is the meaning of the United States that controls." ${ }^{\prime 1}$ That is, when the government mandates that contractual agreements include certain language, it is the government's understanding of that language that governs - not the parties' intentions. Because the United States had taken the position in an amicus brief that Paragraph Four set a floor and not a ceiling, its interpretation controlled.

Judge Lipez argued that such a principle was contrary to the basic precepts of contract law. The original parties to the mortgage might, without violating the government's reading of Paragraph Four, have inserted a clause to prevent the bank from demanding more flood insurance than that required by law-setting the federal requirements as a ceiling. Why, then, should the plaintiff be precluded from showing that this was their actual and reasonable understanding of the mandatory Paragraph Four? ${ }^{62}$ "[G]iven the paramount importance of the parties"

55. It appears that the plaintiff may have first made this argument on appeal. See 738 F.3d at 46566 (opinion of Lipez, J.); id. at 469-70 (opinion of Kayata, J.). For my purposes, it is worth bracketing any procedural issues that might be raised.

56. Kolbe v. BAC Home Loans Servicing, L.P., No. 11-10312-NMG, 2011 WL 3665394, at *3-5 (D. Mass. Aug. 18, 2011).

57. Kolbe v. BAC Home Loans Servicing, LP, 695 F.3d 111, 122 (1st Cir. 2012).

58. Kolbe, 738 F.3d at 436 (opinion of Lynch, J.).

59. Id. at 456 (opinion of Lipez, J.).

60. Id. at 436. See also id. at 440-42 (discussing § 211(2) and the interpretation of "uniform clauses").

61. Id. at 437. See also id. at 442-44.

62. Id. at 458-62. 
intentions in resolving contract disputes, it is a considerably more dramatic departure from basic contract law to accept the government's interpretation of ambiguous language as decisive where both parties to a private contract manifested a contrary, consistent understanding of the language." ${ }^{63}$

Which is the correct approach to mandatory clauses such as the one at issue in Kolbe? One might think of mandatory clauses as special types of mandatory terms. Rather than requiring the insertion of Paragraph Four, the federal government might have simply mandated that all FHA-insured borrowers carry a certain amount of insurance. That is, the government might have imposed a mandatory term on FHA-insured mortgage contracts, without mandating that they include a clause describing it. And a mandatory term might have done equally well at advancing the government's presumable interests in protecting lenders and assuring that homeowners carried sufficient insurance.

So why require the boilerplate clause? One way to understand Paragraph Four is not as part of the parties' agreement, but as something like a warning label designed to inform them of a mandatory term of their contract. It is as if the Code, in addition to imposing a mandatory duty of good faith, also required that every written agreement for the sale of goods include the words, "Each party shall be under a duty of good faith in the performance and enforcement of this contract." Such a clause would not be the reason parties are subject to the duty of good faith, but a notice to them of the fact that they are subject to that duty.

Call this the "notice theory" of mandatory clauses: a mandatory clause does not express terms to which parties need agree, but is a notice of mandatory terms imposed by law. The above two paragraphs are not a knock-down argument for the notice theory. But it would be odd for the government to impose a mandatory clause for another reason. More to the point, it is difficult to imagine why the government would want to require that contractual agreements include specific language, and then leave it up to the parties to attach their own meanings to it. The notice theory suggests that the outcome in Kolbe was correct. Because the government read Paragraph Four as a ceiling and not a floor, it gave the boilerplate clause that meaning-even if the parties thought otherwise. ${ }^{64}$

If the notice theory explains mandatory clauses and justifies the outcome in Kolbe, it does not answer all the questions mandatory clauses pose. Judge Lipez, for example, emphasized that the federal government first clarified its reading of Paragraph Four in an amicus brief filed five years after the parties entered into

63. Id. at 460. See also id. at 468 ("But where the language is ambiguous, the parties construe it the same way, and their interpretation does not conflict with federal policy, it does violence to traditional contract law precepts to allow the government's explanation of its murky language to override the parties' meeting of the minds.").

64. Although there is not much literature on mandatory clauses, they occasionally appear. With regard to insurance contracts, Susan Randall writes: "It is clear that where policy provisions are mandated by statute or regulation, concerns about freedom of contract are irrelevant. Courts must interpret such provisions using principles of statutory construction and enforce them with the goal of effectuating the legislature's or regulator's intent." Susan Randall, Freedom of Contract in Insurance, 14 CONN. INS. L.J. 107, 136 (2007). 
the agreement. ${ }^{65} \mathrm{He}$ found it problematic that the outcome of the case entailed that "the government's newly offered construction of Paragraph 4 not only governs mortgage agreements entered into subsequent to the pronouncement, but also operates retroactively to supersede the shared understanding of private parties who previously entered into mortgages containing the flawed language." ${ }^{66}$

Judge Lipez's objection suggests two questions. First, what should be done when the required contractual notice is ambiguous or otherwise misleading? Should the government's poor drafting affect the underlying mandatory term's applicability or content? Second, can the government change its interpretation of a mandatory clause? It is fairly clear that the government might change a mandatory term in an existing contract. Changes to the minimum wage do just that. So did Javins v. First National Realty Corporation's recognition of the mandatory implied warranty of habitability in existing residential leases. ${ }^{67}$ Should the case be different if the government has required detailed notice of a mandatory term and one or both parties has relied on that notice? ${ }^{68}$

I raise these questions not to answer them, but simply to point out that mandatory clauses raise a special set of issues with respect to the parties' intent. Even if the meaning of legally-mandated boilerplate does not depend on the parties' understanding of it, there might be instances in which courts should take that understanding into account. That said, the broader point remainsmandatory clauses are an important example in which, because they originate in boilerplate, the terms of the parties' contract might depart from the parties' intent.

IV

\section{STANDARD FORMS}

As the term is used in this Article, a standard form is a contractual writing drafted by a private person or entity that is not a party to the contract. A standard form might be authored by a for-profit business, such as Bloomberg or Westlaw, an industry association, such as the American Institute of Architects, or a mission-driven nonprofit, such as Creative Commons or the Open Source Initiative. ${ }^{69}$ Some standard forms are intended to be used without modificationlike a mandatory clause must be. But there is nothing stopping individual parties from modifying a standard form, and often parties do. When employed without

65. Kolbe, 738 F.3d at 455 (opinion of Lipez, J.).

66. Id. at 458 (internal citation omitted).

67. See 428 F.2d 1071 (D.C. Cir. 1970). Javins defined a landlord's duties using the standards set forth in D.C. Housing Regulations, which themselves change over time. Id. at 1080.

68. For a relevant decision, see Fies v. State Farm Lloyds, 202 S.W.3d 744, $747-48$ (Tex. 2006) (holding that an unambiguous mandatory exclusion clause in an insurance contract precluded deference to a state regulatory agency's opinion expressed in an amicus brief that it had a different meaning).

69. For an overview of the nonprofit market, see generally Kevin Davis, The Role of Nonprofits in the Production of Boilerplate, 104 MICH. L. REV. 1075 (2006). 
modification, however, standard forms are yet another species of contract boilerplate.

It is not obvious that the fact that parties use a form drafted by a private third party without modification should, in itself, make a difference in the interpretation of their agreement. The question was raised in a 2004 Oklahoma appellate case, Stephenson $v$. Onoek Resources $C o .^{70}$ At issue was the meaning of two standard forms used in the oil and gas industry, one drafted by the American Association of Petroleum Landmen and the other by the Council of Petroleum Accountants Societies. Although the forms stipulated that overhead rates paid to the operator "shall be adjusted . . . each year,"71 the parties had not made adjustments in certain years. When a new operator took over the contract, it argued that the "shall" language mandated adjustments, and therefore the current overhead rate should be increased to take account of adjustments not made in prior years. ${ }^{72}$ Both the trial and the appellate courts found the standard form ambiguous and held that its meaning was properly a question for the jury.

The trial court instructed the jury to consider prior dealings and focus on the parties' actual intent. On appeal, the operator argued that the instructions should have instead tracked the language of Second Restatement section 211(2), which provides that a standardized agreement "is interpreted wherever reasonable as treating alike all those similarly situated, without regard to their knowledge or understanding of the standard terms of the writing."73 The operator argued that under section 211(2), the jury should not have been instructed to make a finding as to the parties' actual intent, and should presumably be prevented from considering evidence such as course of performance or previous dealings. ${ }^{74}$

The Oklahoma appellate court rejected that argument. "If there is an ambiguity in a standard industry form, the trier of fact may look to extrinsic evidence, such as industry custom and usage, to determine the intent of the parties. However, unlike in $\S 211$, the intent of the parties still controls." 75 This would appear to be the right result. Unlike the mandatory clause at issue in Kolbe, there is no reason to think that the oil and gas industry's standard forms embodied terms that were in the public interest, much less mandated by law. If the primary goal of contract law is to enforce the parties' actual agreement, evidence of their understandings of an ambiguous standard form would seem to be relevant.

What about section 211(2)'s suggestion that standardized agreements be "interpreted wherever reasonable as treating alike all those similarly situated,

70. 99 P.3d 717 (Okla. Civ. App. 2004).

71. Stephenson, 99 P.3d at 719.

72. Id. at 720 .

73. SECOND RESTATEMENT $\S 211(2)$. A standardized agreement is one "where a party ... has reason to believe that like writings are regularly used to embody terms of agreements of the same type." Id. § 211(1).

74. Stephenson, 99 P.3d at 722 .

75. Id. at 722-23. 
without regard to their knowledge or understanding"? ${ }^{76}$ Part V examines the history of purpose of section 211. Here it is enough to observe that no matter what the intent of its drafters, it would be odd to apply such a rule to all standardform boilerplate. The mere fact that parties have used a standard form does not on its own provide a reason to ignore evidence of their actual intent.

But standard forms sometimes are put to special purposes. In markets that significantly benefit from uniformity of terms, participants might employ standard-form boilerplate to achieve such uniformity. The remainder of this part discusses two examples of such markets-derivatives and insurance-and techniques courts might use to achieve uniform construction of standard-form boilerplate therein.

In re Lehman Brothers Holdings Inc. v. Intel Corp., a 2015 district court decision, addressed the proper construction of the International Swaps and Derivatives Association (ISDA) Master Agreement for credit default swaps. ${ }^{77}$ As part of a stock buy-back plan, Intel had paid a Lehman subsidiary $\$ 1$ billion to purchase shares of Intel stock and then transfer those shares back to Intel. After Intel paid the $\$ 1$ billion but before the date for delivery, Lehman Brothers declared bankruptcy and so failed to deliver the shares. At issue was the Agreement's definition of "Loss" as the amount the non-defaulting party "reasonably determines in good faith to be its total losses and costs." 78

The details of the interpretive question are less important in this context than the way that the district court went about answering it. As one would expect, the court began with the text's plain meaning. But it supplemented that analysis by considering both an amicus brief submitted by the ISDA, which explained the organization's understanding of the clause,$^{79}$ and an expert report from a principal drafter of the ISDA Master Agreement, which described the committee's reasoning in creating the clause. ${ }^{80}$ The court did not explain or attempt to justify its use of these extrinsic materials. But that use is consistent with the court's endorsement of the proposition that "[i]t is axiomatic that [ISDA standard forms] should, as far as possible, be interpreted in a way that serves the objectives of clarity, certainty and predictability." ${ }^{81}$

Lehman Brothers is not a case in which the court prevented the parties from presenting evidence of their actual intent. Still, there is no suggestion in the opinion that evidence of the parties' intent was the least bit relevant. Nor did the court identify any evidence that the parties were aware of the extrinsic materials it did use: the ISDA's reading of the clause or its drafting history. Instead, the court ascribed to the parties, without discussing any evidence, a more general

76. See SECOND RESTATEMENT $\S 211(2)$.

77. In re Lehman Bros. Holdings., Inc. v. Intel Corp., No. 08-13555 (SCC), 2015 WL 7194609, at *9 (S.D.N.Y. Sept. 16, 2015).

78. Id. at $* 6$

79. Id. at $* 11, * 12, * 15, * 18$.

80. Id. at $* 12, * 19$.

81. Id. at *11 (quoting Lomas v. JFB Firth Rixson Inc., [2010] EWHC 3372 (Ch), If 53). 
intent: "To the extent they have adopted the ISDA standard forms, it is reasonable to infer that the parties have no quarrel with ISDA's intention that 'transactions that use ISDA standard form documents and definitions . . . are enforced so as to promote legal certainty and hence, market stability." 82 That presumed-or perhaps better, presumptive-intent effectively authorized construction of the parties' agreement without reference to their actual understandings of its terms.

The crucial difference between the oil and gas lease at issue in Stephenson and the ISDA Master Agreement at issue in Lehman Brothers is the role of uniform terms in each market. Although the oil and gas industry might benefit from a single industry-wide standard-form lease - which would make it easier, for example, for the secondary market to price leases ${ }^{83}$ - the market has yet to adopt one. Parties can choose among "hundreds of different preprinted forms," each with slightly different formulations of common lease terms and many with distinctive additional terms. ${ }^{84}$ In such a market, there is relatively little to be gained from uniform judicial interpretation of any one standard form - or what benefit there is does not outweigh the reasons to enforce parties' actual understanding of their agreements.

The over-the-counter derivatives market is very different. In its Lehman Brothers brief, the ISDA reported that ninety percent of derivatives transactions globally used the ISDA Master Agreement. ${ }^{85}$ And contractual uniformity has been important in the development of the market. In addition to reducing drafting costs - a feature the ISDA Master Agreement shares with other standard forms - standardization has been credited with the enormous increases in market liquidity since the forms were introduced. ${ }^{86}$ In order to realize these benefits, the derivatives market requires not only uniformity of language, but also

82. Id. (quoting not the ISDA's amicus brief in the case at bar, but ISDA's Brief of Amicus Curiae in Support of the Brief of Defendant-Appellant at 6, Aon Fin. Prods. v. Societe Generale, 476 F.3d 90 (2d Cir. 2006) (No. 06-1080-CV)).

83. See Henry T. Greely, Contracts as Commodities: The Influence of Secondary Purchasers on Form Contracts, 42 VAND. L. REV. 133, 149-52 (1989) (discussing institutional challenges faced by the oil and gas industry arising from lack of standardized lease forms).

84. Id. at 151. A more recent study from 2001 found "a considerable level of contractual diversity among the leases sampled... [based in part] upon frequent modifications to the lease form either by adding-to or striking-out language, or by the incorporation of special terms attached as an addendum or exhibit to the lease form." David E. Pierce, The Renaissance of Law in the Law of Oil and Gas: The Contract Dimension, 3 OIL \& GAS NAT. RESOURCES \& ENERGY J. 515, 525 (2017).

85. ISDA's Brief of Amicus Curiae in Support of Defendant Intel Corporation's Motion for Summary Judgment at 1, In re Lehman Bros Holdings Inc., No. 08-13555 (SCC) (S.D.N.Y. Jan. 20, 2015).

86. See Chairman Alan Greenspan, Remarks to the Federal Reserve Bank of Chicago's 41st Annual Conference on Bank Structure, Risk Transfer and Financial Stability 7 (May 5, 2005), https://fraser.stlouisfed.org/title/452/item/8851 [https://perma.cc/FVP2-PQU8] (discussing the effect of the ISDA's 1999 standardized documentation for credit derivatives). Scholars who write on standardization of terms often use the derivative markets as an example of successful standardization. See, e.g., Gelpern, supra note 14, at 39-41; Choi \& Gulati, Contracts as Statutes, supra note 13, at 114244; Greely, supra note 83, at 142. 
uniformity of terms - in other words, uniform judicial construction of ISDA standard forms.

In thinking about ways to achieve contractual uniformity, Stephen Choi and Mitu Gulati have suggested that "contracting parties should have the ability to designate a standard-setting entity to provide a definitive source of interpretive authority for the contract," and that when parties do so courts should be required "to adopt the interpretation of the designated standard setter." 87 The ISDA Master Agreement does not provide that the ISDA shall be a source of authority for interpreting it. ${ }^{88}$ Still, the Lehman Brothers court's reliance on the ISDA brief and the agreement's drafting history is in line with Choi and Gulati's proposal. Judicial deference to a drafter's understanding of its own form is a way to achieve uniform construction of it. ${ }^{89}$

Lehman Brothers is also relevant to the theory of legal interpretation generally, as it illustrates the occasional importance of distinguishing between the author of a legal writing and the person or persons who authorize it. ${ }^{90}$ When two parties together draft a contractual writing and each agrees to it, there is no difference between author and authorizer. The same is presumably true when the President tweets an executive order. ${ }^{91}$ In other instances, however, one person might author a document and another authorize it. Usually when this is the case, it is the authorizer's intent that matters. Thus to the extent courts care about legislative intent, they look to the understanding of legislators, not of the legislative staffers who drafted the text. The same rule usually applies when parties use a standard form: it is the parties' understanding that controls, not that of the author. But sometimes the law might look to the author's intent, even at the expense of the authorizer's. First-generation constitutional originalists, for example, focused on the understandings of the Framers at the Constitutional

87. Choi \& Gulati, Contracts as Statutes, supra note 13, at 1162 .

88. See ISDA 2002 Master Agreement between Bank of America, N.A. and LKQ Corp. (Mar. 22, 2011), https://www.sec.gov/Archives/edgar/data/1065696/000119312511118050/dex101.htm [https:// perma.cc/83UR-YV5B].

89. In addition to its brief in Lehman Brothers, ISDA has submitted at least three other amicus briefs on the interpretation of its standard forms. Brief for Defendant-Appellant Société Générale as Amicus Curiae, Aon Fin. Prod., Inc. v. Société Générale, 476 F.3d 90 (2d Cir. 2006) (No. 06-1080-cv) (addressing settlement obligations under a credit default swap that was based on standard ISDA documentation); Brief for Defendant-Appellant-Cross-Appellee Lehman Brothers Special Financing, Inc., Fin. One Pub. Co. v. Lehman Bros. Special Fin. Inc., 414 F.3d 325 (2d Cir. 2004) (Nos. 03-9049(L), 03-9096(XAP)) (addressing the determination of interest amounts payable upon early termination pursuant to the ISDA Master Agreement); International Swaps and Derivatives Ass'n, Inc.'s Reply Memorandum of Law in Further Support of its Motion For Leave to File a Brief Amicus Curiae in Support of Defendant Lehman Bros. Special Financing Inc.'s Motion to Reconsider, Amend or Alter Judgment pursuant to Rules 59(e) and 60(b) of the Federal Rules of Civil Procedure, Fin. One Pub. Co. Ltd. v. Lehman Bros. Special Fin., Inc., No. 00-CV-6739-CBM, 2003 WL 21638214 (S.D.N.Y. July 11 2003) (addressing the determination of interest amounts payable upon early termination pursuant to the ISDA Master Agreement), modified, No. 00-CV-6739-CBM, 2003 WL 22056983 (S.D.N.Y. Sept. 4, 2003).

90. I discuss the distinction in Gregory Klass, Contracts, Constitutions, and Getting the Interpretation-Construction Distinction Right, 18 GEO. J. L. \& PUB. POL'Y (forthcoming 2020).

91. See Katherine Shaw, Speech, Intent, and the President, 104 CORNELL L. REV. (forthcoming 2019) (providing a conceptual framework for courts assessing presidential speech and intent). 
Convention, though it was not the Framers who authorized the document. ${ }^{92}$ And the Supreme Court has occasionally looked to framer intent by relying on draft provisions antedating the final document produced by the Committee on Style. ${ }^{93}$ Judicial interpretation of some standard form contract boilerplate provides another example. Where there is a need for uniform contract terms in a market that uses a standard form, it might make sense to look to the meaning a form's author attaches to it, rather than to the understandings or intentions of the parties who authorize its use in individual transactions.

That said, the mere fact that uniformity of terms is important in a market where a standard form is used is not always a sufficient reason for courts to defer to the form's author when interpreting it. The insurance market provides an example, and illustrates how difficult it can be to achieve uniform terms.

There is widespread agreement that uniformity of terms has significant benefits in the insurance market. ${ }^{94}$ Many insurance policies must be pre-approved by state regulators, a process that industry-wide standard forms vastly simplify. Insurers pool actuarial data to understand the costs of various types of coverage, calculations that are much easier when terms are uniform across policies. And there exists a robust reinsurance market, which like any secondary market benefits from uniformity when setting prices.

For these and other reasons, large portions of the U.S. insurance industry use standard forms. Most significantly in this context, almost all property and general liability insurers employ standard forms drafted by the leading industry association, the Insurance Services Office (ISO). Given the importance of uniform terms in the industry, it is generally agreed that these contracts should be interpreted uniformly. Thus section 2 of the recently approved Restatement of the Law of Liability Insurance provides that the interpretation of an insurance policy is a question of law and explains in the comments that "[j]udicial decisions regarding the interpretation of standard-form terms ... are subject to de novo review on appeal and provide stare decisis." ${ }^{95}$ Similarly, in Couch on Insurance one finds:

The judicial construction placed upon particular words or phrases made prior to the issuance of a policy employing them will be presumed to have been the construction intended to be adopted by the parties; otherwise the language of the policy should have been modified to make the contrary intent clear. ${ }^{96}$

92. See Lawrence B. Solum, Originalism and Constitutional Construction, 82 FORDHAM L. REV. 453, 462-63 (2013) (describing the "Proto-Originalist" theories of Edwin Meese and others).

93. For a discussion of four examples, see William Michael Treanor, Framer's Intent: Gouverneur Morris, the Committee of Style, and the Creation of the Federalist Constitution 43-50 (Feb. 5, 2019), https://ssrn.com/abstract=3383183 [https://perma.cc/8EUR-ZZT2]. But see Utah v. Evans, 536 U.S. 452, 496 (2002) (Thomas, J., dissenting) ("I focus on the words of the adopted Constitution.").

94. For a summary, see KENNETH S. ABRAHAM, INSURANCE LAW AND REGULATION: CASES AND MATERIALS, 31-37 (4th ed. 2005). See also RESTATEMENT OF THE LAW OF LIABILITY INSURANCE § 2 cmt. d (AM. LAW INST. 2019).

95. Id. $\S 2 \mathrm{cmt} . \mathrm{b}$.

96. 2 COUCH ON INSURANCE $§ 22: 40$ (S. Plitt et al. eds., 3d ed. June 2019) [hereinafter COUCH ON INSURANCE]. 
An insured's understanding of policy terms therefore takes second place to uniformity of terms throughout the market. The comments to section 2 note that "current practices in the consumer-insurance market make it unlikely that a consumer will receive a complete copy of a liability insurance policy before purchase," and express pessimism about whether consumer comprehension of terms is an achievable goal: "It is not assumed or expected that consumers ordinarily read their insurance policies, nor that legal rules can do very much to change consumer behavior in that regard." ${ }^{97}$ That is not to say that consumers have no expectations as to coverage. But individual consumers' expectations are of limited relevance. As in the derivatives market, uniformity in the construction of boilerplate insurance forms can displace party intent.

What is less clear in the insurance market is how to achieve uniform construction of standard-form insurance policies. A partial canonical answer is that policies should be interpreted according to their plain meaning. By excluding evidence of context and cabining judicial discretion, plain meaning rules are in theory more likely to produce uniform constructions of standard forms. Thus whereas the Second Restatement of Contracts advocates a highly contextualist approach to the interpretation of even integrated writings, section 3 of the Restatement of the Law of Liability Insurance maintains that an insurance policy's plain meaning controls: ${ }^{98}$ "The plain-meaning approach promotes consistency of interpretation of insurance policies using the same language in similar contexts, giving the parties to standardized insurance policies greater confidence that they will be uniformly enforced." 99 Whether this is true in practice depends, of course, on just how plain plain meaning is - on whether the Second Restatement is correct that "meaning can almost never be plain except in a context." 100

Whether the plain-meaning approach promotes consistency in interpretation and enforcement also depends on whether courts are willing to ignore extrinsic evidence that the parties intended something other than what the standard form said. This fact perhaps explains insurance law's heavy reliance on waiver and estoppel. ${ }^{101}$ By permitting courts to apply estoppel when an insurer or its agent represents terms contrary to those in the policy, the law removes the temptation to use that evidence to interpret the policy. The boilerplate's meaning remains fixed, though the case outcome reflects salient facts about the transaction.

The limitations of the plain-meaning approach, and what might be done when plain meaning runs out, can be seen in the tortured history of the phrase "sudden

97. RESTATEMENT OF THE LAW OF LIABILITY INSURANCE $§ 2 \mathrm{cmt}$. d (AM. LAW INST. 2019).

98. Id. § 3.

99. Id. cmt. a.

100. SECOND RESTATEMENT $\S 212 \mathrm{cmt}$. b. See also CORBIN, supra note 46, at $\S 542,100-02$ ("[S]ome of the surrounding circumstances always must be known before the meaning of the words can be plain and clear.").

101. See Restatement of the LAW OF Liability InSURANCE $§ \S 5$ \& 6 (AM. LAW InSt. 2019) (describing the two doctrines). 
and accidental" in comprehensive general liability (CGL) policies. ${ }^{102}$ The insurance industry has long used standard-form CGL policies drafted by the ISO and its precursor, the Insurance Rating Board (IRB). Between 1970 and 1986, the standard pollution exclusion clause in the IRB policy provided:

This insurance does not apply $* * *$ (f) to bodily injury or property damage arising out of the discharge, dispersal, release or escape of smoke, vapors, soot, fumes, acids, alkalis, toxic chemicals, liquids or gases, waste materials or other irritants, contaminants or pollutants into or upon land, the atmosphere or any water course or body of water; but this exclusion does not apply if such discharge, dispersal, release or escape is sudden and accidental. ${ }^{103}$

After the pollution exclusion clause was issued and widely adopted, Congress and the states passed a number of laws that imposed on businesses strict liability for the cleanup of past pollution. ${ }^{104}$ Those laws put insurers on the hook for huge sums of money based on insureds' or their predecessors' past practices. Because the standard pollution exclusion clause provided coverage for "sudden and accidental" discharges, billions of dollars of insurer liability turned on the meaning of those words. Insurance companies argued inter alia that the plain meaning of "sudden" was a temporal one, from which it followed that the policies did not cover the gradual release of pollutants. Insureds argued that "sudden" can also mean unexpected, and that the clause covered gradual releases. Over the course of several decades of litigation, courts remained divided on the clause's proper reading. ${ }^{105}$

The New Jersey Supreme Court's exhaustive opinion in Morton International v. General Accident Insurance Co. of America illustrates several salient aspects of the imbroglio. ${ }^{106}$ The court began its analysis by following others to find that the plain meaning of "sudden and accidental" corresponded to insurers' temporal readings of it, which would exclude gradual discharges. ${ }^{107}$ Yet as the court itself noted, before the phrase appeared in the pollution exclusion clause it had long been used in boiler and machinery insurance policies, and in those policies had been read by courts to refer to unexpected or undetectable breakages, as

102. For a more detailed discussion of the history of the pollution exclusion clause, see Christopher C. French, Insurance Policies: The Grandparents of Contractual Black Holes, 67 DUKE L.J. ONLINE 40, 56-63 (2017).

103. Penny R. Warren, "Sudden and Accidental" Pollution Exclusions: The Battle Between Insurance Carriers and Insureds Continues, 12 J. NAT. RESOURCES \& ENVTL. L. 243, 244 (1996-97) (emphasis added).

104. Most significantly at the federal level the various Superfund laws, 42 U.S.C. $\S \S 6901-6975$ (2019).

105. See 9 COUCH ON INSURANCE $§ 127$ ("[j]urisdictions are split as to the meaning of the terms 'discharge, dispersal, seepage, migration, release or escape."'). See also Morton Int'l, Inc. v. Gen. Acc. Ins. Co. of Am., 629 A.2d 831, 855-70 (N.J. 1993) (reviewing judicial treatment of the pollution exclusion clause).

106. Morton, 629 A.2d at $855-70$.

107. "Although the word 'sudden' is hardly susceptible of precise definition ... we are persuaded that 'sudden' possesses a temporal element, generally connoting an event that begins abruptly or without prior notice or warning, but the duration of the event - whether it lasts an instant, a week, or a monthis not necessarily relevant to whether the inception of the event is sudden." Id. at 847. See also id. at 87172 (discussing the literal, temporal meaning of "sudden"). 
distinguished from instantaneous ones. ${ }^{108}$ In other words, there was a good argument that "sudden and accidental" was a technical term in the insurance industry. But how to tell? Although the plain meaning rule specifies that technical terms are to be construed in accordance with their technical meanings, it does not specify how to determine whether a phrase is being used in its technical sense. Plain meaning, in this instance, was not plain-despite the Morton court's suggestion that "sudden and accidental" was not ambiguous.

The Morton decision is also interesting in this context because of the court's attitude toward two aspects of the history of the pollution exclusion clause. First, the court rejected an argument, raised in an amicus brief submitted by Aetna, that internal IRB documents showed the drafters intended "sudden" to apply in the temporal sense only. ${ }^{109}$ This seems right. It has been argued that because standard-form insurance policies are in some ways similar to statutes, courts should be receptive to receiving evidence of a policy's drafting history, in the same way they consider legislative history. ${ }^{110}$ But there are important differences. Whereas a legislature hopefully represents the public at large, the ISO primarily represents only one side of an insurance transaction: that of the insurer. And it is insurers that largely control the ISO's agenda. Christopher French has suggested, for example, that the ISO does not document its own drafting process in order to keep that information out of litigation. Because insurers generally take the position that policy language is unambiguous so as to avoid contra proferentem, insurers benefit when the production of standard policy forms is a black box. ${ }^{111}$

The ISO's partisan nature distinguishes it from the ISDA, which generally represents the interests of both sides in a derivatives sale. Consequently, whereas it can be appropriate for courts to look to the ISDA Master Agreement's drafting history and to the ISDA's present position on its meaning, it would be inappropriate to give similar weight to the drafting history of ISO standard forms or to ISO's present understanding of them. ${ }^{112}$ In fact, given the ISO's partisan nature, there would be good reasons not to defer to its interpretations even if the ISO followed Choi and Gulati's suggestion and wrote its form policies to "designate [it as] a definite source of interpretive authority." 113

108. Id. at 862-65. See also Carl A. Salisbury, Pollution Liability Insurance Coverage, The StandardForm Pollution Exclusion, and the Insurance Industry: A Case Study in Collective Amnesia, 21 ENVTL. L. 357, 379-82 (1991) (discussing judicial construction of the term in boiler and machinery policies).

109. Morton, 629 A.2d at 855.

110. Jeffrey W. Stempel, The Insurance Policy as Statute, 41 MCGEORGE L. REV. 203, 219-22 (2010).

111. French, supra note 102, at 59-60. See also John Randolph Prince, III, Where No Minds Meet: Insurance Policy Interpretation and the Use of Drafting History, 18 VT. L. REV. 409, 414 (1994) (noting that insurers and the ISO have vigorously resisted discovery requests for policy drafting histories).

112. This is not to say that courts should never use the drafting history of standard-form insurance policies. The history might suggest that the insured's understanding is a reasonable one, see Prince, supra note 111 , at 436, or that the industry itself adopted the insured's preferred interpretation. See, e.g., Maricopa Cty. v. Ariz. Prop. \& Cas. Ins. Guar. Fund, No. 2 CA-CV 98-0076, 2000 WL 35937314, at *67 (Ariz. Ct. App. 2000) (treating IRB communications to regulators as probative of insurers' understanding of the clause).

113. Choi \& Gulati, Contracts as Statutes, supra note 13, at 1162. 
Second, although the Morton court discounted evidence of the standard CGL policy's drafting history, it gave considerable weight to the IRB's statements to insurance regulators regarding the effect of the pollution exclusion clause. As the New Jersey Attorney General emphasized in an amicus brief, when the clause was added to the CGL form, the IRB repeatedly represented to state regulators that it affected no major change in coverage. ${ }^{114}$ In explaining the relevance of these representations, the Morton court did not identify evidence that any parties were aware of them. Instead, it reasoned that

if given literal effect [i.e., a temporal meaning], the standard clause's widespread inclusion in CGL policies would limit coverage for pollution damage to so great an extent that the industry's representation of the standard clause's effect, in its presentation to New Jersey and other state insurance regulatory agencies, would have been grossly misleading. ${ }^{115}$

The court therefore applied regulatory estoppel to hold insurers to the nontemporal meaning of "sudden." "[T]o construe the pollution-exclusion clause [literally] would, in this Court's view, violate this State's strong public policy requiring regulation of the insurance business in the public interest, and would reward the industry for its misrepresentation and nondisclosure to state regulatory authorities." 116

This argument recalls Kolbe's approach to mandatory clauses. Given the highly regulated nature of insurance contracts ${ }^{117}$ perhaps courts should defer to regulators' understanding of their terms - especially when policy language is subject to regulatory approval. And in fact, state regulators, attorneys general, and other governmental entities filed amicus briefs in at least twenty-six cases involving the proper construction of the pollution exclusion clause. ${ }^{118}$

Although there is a good argument that courts should defer to regulators' understandings of terms in insurance policies subject to regulatory approval, it is not their practice to do so. As Susan Randall summarizes, "[c]ourts generally interpret and construe insurance policies without acknowledgment that insurance regulators approved the language, often with a resulting focus on the intent of the parties and the public policy of protecting freedom of contract."119

114. Morton, 629 A.2d at 851 (discussing arguments of the New Jersey Attorney General); see also $i d$. at $851-55$ (discussing the history of state regulatory approval). For more on the relevance of the industries' representations to regulators and the drafting history of the pollution exclusion clause, see Prince, supra note 111, at 422-29.

115. Morton, 629 A.2d at 847.

116. Id. at 847. See also id. at 848 ("[W]e deem appropriate construing the pollution-exclusion clause in a manner consistent with the objectively-reasonable expectations of the New Jersey and other state regulatory authorities, because only those regulatory authorities were presented with an opportunity to disapprove the clause."). After embracing regulatory estoppel argument, the Morton court went onunnecessarily in my opinion - to hold that "the 'reasonable expectations' of the New Jersey insurance regulatory authorities should be imputed to those insureds to whom CGL policies with standard pollution-exclusion clauses were issued after the clause had been approved on the basis of the IRB memorandum." Id. at 875.

117. For a summary, see generally Randall, supra note 64, at 126-35.

118. See Salisbury, supra note 108, at 401-04 (listing state amicus briefs).

119. Randall, supra note 64 at 137. See id. at 135-43 (providing an overview of judicial deference to 
Morton is the exception rather than the rule. Although uniform construction of standard-form insurance policies might be secured through the active participation of state regulators, that is not the case today.

David Horton has suggested yet another tool for achieving uniformity in the construction of "mass-produced contracts": a robust version of contra proferentem, in which the doctrine applies as soon as a writing is determined to be ambiguous, rather than as a tie-breaker after all the evidence is in. ${ }^{120}$ Horton's focus is on party-drafted contracts of adhesion. But courts often apply contra proferentem to insurance policies, ${ }^{121}$ and, as Horton observes, strict contra proferentem originated in their construction. ${ }^{122}$ If courts can agree on whether a standard from is ambiguous, consistent interpretation of facial ambiguities against the insurer can be another tool for securing the uniform construction of at least some standard form policies.

That said, strict contra proferentem does not always produce uniform constructions of the same words. Consider the meaning of "per occurrence" in deductibles and coverage caps, language that has been part of the standard CGL policy since 1980. There has been much litigation concerning whether "occurrence" refers to an event causing one or more losses or to each resulting event of loss. Michigan Chemical Corp. v. American Home Assurance Co., for example, addressed a case in which a chemical company accidently filled bags with the wrong product and shipped them to a feed company, which then distributed the product to many dairy farmers, poisoning their herds. ${ }^{123}$ At issue was whether the "per occurrence" cap in the chemical company's CGL policies referred to the act causing the losses, in which case there was a single occurrence (shipping the mislabeled chemical) to which the policies' aggregate twenty-eight million dollar cap applied, or whether it referred to the downstream events that generated the loss (the poisoned herds), in which case each farmer lawsuit against the company concerned a separate occurrence. As others have observed, construing "per occurrence" in favor of the insured can lead to different constructions in different cases. ${ }^{124}$ If, like in Michigan Chemical Corp., the policy's deductible and caps are low relative to the magnitude of the aggregate loss, the insured is more likely to prefer defining "occurrence" as each downstream loss, meaning the cap applies to each occurrence separately. If the deductible and caps are relatively high, the insured is likely to prefer defining

regulators in the interpretation of insurance policies).

120. David Horton, Flipping the Script: Contra Proferentem and Standard Form Contracts, 80 U. COLO. L. REV. 431, 436 (2009). See generally id. at 473-84.

121. See 2 COUCH ON INSURANCE $§ 22: 14$.

122. See Horton, supra note 120 , at 436.

123. 728 F.2d 374 (6th Cir. 1984).

124. See, e.g., Michael Murray, The Law Describing Accidents: A New Proposal for Determining the Number of Occurrences in Insurance, 118 YALE L.J. 1484 (2009). For another example where interpreting in favor of the insured gives inconsistent results, see Carlson Mktg. Grp., Inc. v. Royal Indem. Co., 517 F. Supp. 2d 1089, 1100-03 (D. Minn. 2007) (interpreting an ambiguous anti-stacking clause). 
"occurrence" as the originating cause, resulting in fewer occurrence and therefore a lower total deductible.

As it happens, courts have largely converged on a single reading of "per occurrence" in CGL policies, with a clear majority reading "occurrence" to refer to the causal event, rather than losses caused. ${ }^{125}$ The court in Michigan Chemical Corp. chose to resolve the case on this basis. "[W]here the courts over such an extended period of time have reached a virtually uniform result in interpreting the term "occurrence," the term is "unambiguous and require[s] no further construction." 126 Although the above sentence might cause a linguist to scratch her head, the reliance on judicial consensus-however achieved-is perfectly understandable when the goal is uniform construction of a standard form.

This is a good place to return to Michelle Boardman's worry, discussed in Part II, that application of contra proferentem and stare decisis can render policy language "a private conversation between drafters and courts," which policy holders are unlikely to understand. ${ }^{127}$ Part II argued that boilerplate formalities are generally ill-suited to the goal of empowering parties to get the terms they want. Parties might be unaware of earlier judicial decisions construing the language they are using. And because boilerplate starts life as an ordinary contract clause, a boilerplate formality does not put users on notice that it has been given a specific legal effect.

Sometimes, however, the goal of boilerplate formalities is not to empower parties to get the terms they want, but to achieve uniformity of terms in a market. Where this is the case, the gains from the uniform construction of boilerplate might be worth the costs in party comprehension. This is not to say the costbenefit analysis will always produce that result, or that party comprehension must always be sacrificed at the altar of uniformity. Especially concerning, for example, is Boardman's suggestion that after an improper denial of coverage, a consumer might decide not to sue in reliance on a policy's apparent plain meaning. ${ }^{128}$ That said, in the aggregate non-drafters might benefit from the uniform construction of a standard form - even if that construction sometimes results in discontinuities between boilerplate terms and one or both parties' reasonable understanding of the deal.

125. See 12 COUCH ON INSURANCE $\S 172: 12$ ("It has also been stated that the number of acts producing injury or damage, rather than the number of injuries caused, is the key on which definition of 'occurrence' turns in interpreting a 'per occurrence' clause.").

126. Michigan Chem. Corp., 728 F.2d at 379. But see Maddox v. Fla. Farm Bureau Gen., 129 So. 3d 1179, 1182 (Fla. Dist. Ct. App. 2014) (construing "occurrence" against the insurer, where "per occurrence" policy caps were at issue, to refer to each dog bite resulting in injury during a prolonged attack).

127. See Boardman, supra note 48 and accompanying text.

128. Boardman, supra note 48, at 1127. Cf. Meirav Furth-Matzkin \& Roseanne Summers, Consumer Psychology and the Problem of Fine Print Fraud, 72 STAN. L. REV. (forthcoming) (providing evidence that consumers are likely to believe that they are bound by fine print contradicted by express representations); Tess Wilkinson-Ryan, The Perverse Consequences of Disclosing Standard Terms, 103 CORNELL L. REV. 117 (2017) (finding that disclosure of unenforceable onerous terms is likely to cause consumers to believe they are bound by them). 


\section{CONTRACTS OF ADHESION}

Contracts of adhesion are boilerplate writings drafted or chosen by one party and given to the other, or more often to many others, on a take-it-or-leave-it basis. This Part examines contracts of adhesion through the lens of section 211(2) of the Second Restatement of Contracts. Except in Arizona, section 211 has not had a large impact on the law. ${ }^{129}$ Subsection (2), however, addresses itself to the subject of this Article, providing that a standardized agreement "is interpreted wherever reasonable as treating alike all those similarly situated, without regard to their knowledge or understanding of the standard terms of the writing." 130 And courts sometimes cite section 211(2) for that proposition. As noted above, in his Kolbe opinion, Judge Lynch argued that the section 211(2) rule authorized ignoring the parties understanding of the mandatory clause at issue. ${ }^{131}$ At least two judicial decisions have applied section 211(2) to standard form insurance contracts. ${ }^{132}$ And, as will be discussed below, courts have recently begun citing section 211(2) at the class certification stage for the uniform construction of adhesive consumer contracts. The last set of decisions suggest yet another reason for uniformly construing some forms of boilerplate at the expense of party intent.

Section 211(2) is not a model of Restatement precision. ${ }^{133}$ Despite the provision's broad language, section 211 as a whole appears intended to address only contracts of adhesion-not mandatory clauses or standard forms. Thus subsection (3) provides that "[w]here the other [i.e. drafting] party has reason to believe that the party manifesting such assent would not do so if he knew that the writing contained a particular term, the term is not part of the agreement." ${ }^{134}$ And during the American Law Institute (ALI) discussion of section 211, the Reporter, Robert Braucher, stated that the section was about contracts of adhesion,

129. Several scholars have observed that $\S 211$ is remarkable for its apparent lack of influence on judicial decisions. Eric A. Zacks, The Restatement (Second) of Contracts §211: Unfulfilled Expectations and the Future of Modern Standardized Consumer Contracts, 7 WM. \& MARY BUS. L. REV. 733, 757-60 (2016); Edith R. Warkentine, Beyond Unconscionability: The Case for Using "Knowing Assent" as the Basis for Analyzing Unbargained-for Terms in Standard Form Contracts, 31 SEATTLE U. L. ReV. 469, 509 (2008); James J. White, Form Contracts under Revised Article 2, 75 WASH. U. L. Q. 315, 324-25 (1997).

130. SECOND RESTATEMENT § 211(2).

131. See Kolbe, supra note 58 and accompanying text. See also Canel v. Fed. Home Loan Mortg. Corp., No. 85 C 1424, 1985 WL 2929, at*3 (N.D. Ill. 1985) (applying the $\S 211(2)$ rule to an Illinois standard mortgage form).

132. Maricopa Cty. v. Ariz. Prop. \& Cas. Ins. Guar. Fund, No. 2 CA-CV 98-0076, 2000 WL 35937314 , at *7 (Ariz. Ct. App. 2000); Fireman's Fund Ins. Cos. v. Ex-Cell-O Corp., 702 F. Supp. 1317, 1326 (E.D. Mich. 1988).

133. The section appears in the middle of the Second Restatement's provisions that describe the parol evidence rule, which are equally abstruse. See SECOND RESTATEMENT §§ 209-18. For a trenchant criticism of the Second Restatement's treatment of the parol evidence rule, see John E. Murray, Jr., The Parol Evidence Process and Standardized Agreements Under the Restatement, (Second) of Contracts, 123 U. PA. L. REV. 1342 (1975) (discussing the 1973 Tentative Draft sections, which survived largely unchanged in the approved Second Restatement).

134. SECOND RESTATEMENT § 211(3). 
explaining that he had not used the term because "it's French or German, or something, and not English." 135 Courts that cite the section for the construction of mandatory clauses or standard forms take it out of context.

The Restatement also provides only limited authority for section 211(2). During the ALI meeting in which section 211 was discussed, there was only a single mention of subsection (2). In his remarks introducing section 211, Braucher explained subsection (2) as follows:

And then I stated a principle that I thought of as part of the law of nature, but found it surprisingly hard to find somebody who could formulate it; and that is that when you have a standardized agreement, one of the things about it is that it's supposed to be standard, and treat everybody the same way. That has not been said very much in judicial opinions, although there are a lot of cases that carry it out. ${ }^{136}$

Whether "there are a lot of cases that carry it out" is open to question. The decisions cited for the comment to the section all concerned insurance policies, which as noted above are subject to specialized rules of construction. ${ }^{137}$

Nor is it obvious how broadly to read the section 211(2) rule. The provision states that an adhesive contract should be read uniformly without regard to the parties' understandings of it "wherever reasonable." It does not say, however, when it is reasonable or unreasonable to do so, or what factors courts should consider when determining reasonableness. Is the mere fact that the writing is a contract of adhesion enough to support a uniform reading despite evidence of the parties' contrary intent? Or is it only "reasonable" to do so only in a narrow class of cases?

There is some textual evidence for a narrow reading. The Reporter's Note suggests that the section derives from Robert Keeton's 1970 article on the doctrine of reasonable expectations in insurance contracts. ${ }^{138}$ Keeton's most influential claim in that article was that courts tend to honor an insured's "objectively reasonable expectations . . regarding the terms of insurance contracts ... even though painstaking study of the policy provisions would have negated those expectations." 139 But he also suggested a corollary to that principle:

135. Robert Braucher, Friday Afternoon Session, May 22, 1970, 47 A.L.I. ProC. 503, 535 (1970). See also id. at 528 (discussing whether $\$ 211$ "requires is that the stronger party, who submits the adhesion contract or pre- pares the standard form, have reason to believe that the party would not assent if he knew about" a clause); id. at 535-36 ("I think what we have been doing is talking about contracts of adhesion like that fellow who had talked prose all his life.").

136. Id. at 524 .

137. Murray notes that the only illustration for the rule is an insurance case in which the court applied the reasonable expectations doctrine to a policy purchased by a relatively unsophisticated party. See Murray supra note 133, at 1388.

138. RESTATEMENT SECOND § 211, Reporter's Note, 124 (discussing Robert E. Keeton, Insurance Law Rights at Variance with Policy Provisions, 83 HARV. L. REV. 961 (1970)).

139. Keeton, supra note 138 , at 967 . The reasonable expectation doctrine is a clear precursor to $\S 211(3)$, although the Reporter's Note cites other sources and Reporter later suggested that the section "drew heavily on the work of Karl Llewellyn." Robert Braucher, Interpretation and Legal Effect in the Second Restatement of Contracts, 81 COLuM. L. REV. 13, 16 (1981). See Karl N. Llewellyn, The Form or Boiler-Plate "Agreement” in THE COMMON LAW TRADITION: DECIDING APPEALS 367 (1960); K. N. Llewellyn, Review of The Standardization of Commercial Contracts in English and Continental Law, 52 
"The objectively reasonable expectations of applicants and intended beneficiaries regarding the terms of insurance contracts will be honored even though painstaking study of the policy provisions would have negated those expectations." 140

This might appear to be just the case that section 211(2) was intended to address: the rare non-drafter who reads and understands an adhesive contract that contains terms that violate the reasonable expectations of the average nondrafter. Thus the comment on section 211(2) explains that "[t]he result may be to give the advantage of a restrictive reading to some sophisticated customers who contracted with knowledge of an ambiguity or dispute."141 This reading also accords with subsection (3) and its comments, which provide that the nondrafting party's understanding of the agreement sometimes does control. This is the case, for example, when the drafter knows that the non-drafting party would object to an adhesive clause because of "prior negotiations or . . . the circumstances," or because the adhesive clause "eviscerates the non-standard terms explicitly agreed to."142

If this narrow reading of section 211(2) is correct, courts are mistaken to cite it for the broader proposition that standardized agreements are generally to be construed uniformly, with limited regard for the parties' actual intent. That said, the section's wording lends itself to such broad readings. ${ }^{143}$ And there is evidence that this is exactly how at least one member of the ALI understood it: Robert Braucher.

In 1971, Braucher stepped down as Reporter on the Second Restatement to become an Associate Justice on the Massachusetts Supreme Judicial Court. ${ }^{144}$ In 1976, Justice Braucher authored that court's opinion in Carpenter v. Suffolk Franklin Savings Bank. ${ }^{145}$ The case involved an interlocutory appeal from a denial of class certification in a case involving an adhesive mortgage contract. The trial court had denied certification based in part on its reading of an earlier Massachusetts Supreme Court decision "as requiring consideration ... of the individual conduct of the parties to each mortgage and of any further individual

HARV. L. REV. 700, 704 (1939).

140. Keeton, supra note 138, at 974. The Reporter's Note to comment e cites pages 974-77 of Keeton's article, where Keeton discusses this corollary.

141. SECOND RESTATEMENT $\S 211 \mathrm{cmt}$. e. Keeton explains it as follows: "To apply a different rule among various policyholders would produce the result that those who remained ignorant of the terms would receive substantially more protection for their premium dollars than those aware of them." Keeton, supra note 138, at 974.

142. SECOND RESTATEMENT $\S 211 \mathrm{cmt}$. f.

143. Other evidence for a broad reading comes from a suggestion in the comments that uniformity follows from a more substantive rule of construction: "courts in construing and applying a standardized contract seek to effectuate the reasonable expectations of the average member of the public who accepts it." Id. cmt. e. It is not obvious how to square this comment with the rule set forth in $\S 211(3)$.

144. Arthur Taylor von Mehren, Robert Braucher and the Restatement (Second) of Contracts, 67 CORNELL L. REV. 631 (1982).

145. 370 Mass. 314 (Mass. 1976). 
circumstances bearing on their intent." 146 Carpenter held this was an incorrect reading of that decision. In explaining why, Justice Braucher repeated the language of section 211(2) verbatim, giving the section the judicial authority he was unable to find as Reporter. The uniform construction of the adhesive contract meant that resolution of some mortgagees' claims might be used to resolve those of others, providing the requisite basis for class certification. ${ }^{147}$

For over a quarter century after Carpenter, the idea that section 211(2) could be of use in the class certification of contract claims involving adhesive boilerplate appears to have lain dormant. But in the past two decades the section has been increasingly cited for that proposition. Since 2002, at least sixteen judicial opinions have referenced section 211(2) when ruling on a motion for class certification where the plaintiff's claims turned on the construction of an adhesive contract. The pattern in these cases is always the same. In response to the plaintiff's motion to certify the class, the defendant argues that an ambiguity in its own contract can be resolved only with extrinsic evidence, thereby generating differences within the proposed class that defeat one or another prong of the certification requirements of Rule 23 of the Federal Rules of Civil Procedurecommonality, typicality, predominance, superiority, adequacy, or some combination thereof. The plaintiff argues in response, among other things, that because it is a contract of adhesion, the boilerplate must be interpreted uniformly and without regard to individual class members' understandings. In fourteen of the decisions mentioning section 211(2), the court agreed with the plaintiff. ${ }^{148}$ Two of those cases rejected the plaintiff's section 211(2) argument. ${ }^{149}$

These decisions, as well as similar ones not citing section 211(2), suggest a reason for uniformly construing some contract boilerplate that is very different from the reasons identified in Part IV. Part IV argued that a standard form might be construed uniformly because it appears in a market where uniform terms

146. Id. at 321 .

147. Id. at 322 .

148. Gillis v. Respond Power, LLC, 677 F. App'x 752, $756-57$ (3d Cir. 2016); In re TD Bank, N.A. Debit Card Overdraft Fee Litig., 325 F.R.D. 136 (D.S.C. 2018); Feller v. Transamerica Life Ins. Co., No. 2:16-cv-01378-CAS-AJW, 2017 WL 6496803, at*11 (C.D. Cal. 2017); Rodman v. Safeway, Inc., No. 11cv-03003-JST, 2014 WL 988992, at*8 (N.D. Cal. 2014); Vedachalam v. Tata Consultancy Servs., Ltd., No. C 06-0963 CW, 2012 WL 1110004, at*9-10 (N.D. Cal. 2012); Ewert v. eBay, Inc., Nos. C-07-02198 RMW, C-07-04487 RMW, 2010 WL 4269259, at*7 (N.D. Cal. 2010); Menagerie Prods. v. Citysearch, No. CV 08-4263 CAS (FMO), 2009 WL 3770668, at *10 (C.D. Cal. 2009); Herman v. Seaworld Parks \& Entm't, Inc., 320 F.R.D. 271, 294 (M.D. Fla. 2017); Petersen v. Am. Gen. Life Ins. Co., No. 3:14-cv-100J-39JBT, 2016 WL 7365187, at *10 (M.D. Fla. 2016); In re Checking Account Overdraft Litig., 307 F.R.D. 630, 642 (S.D. Fla. 2015); In re Checking Account Overdraft Litig., 286 F.R.D. 645,654 (S.D. Fla. 2012); In re Checking Account Overdraft Litig., No. C 06-0963 CW, 2012 WL 12877717, at *8 (S.D. Fla. 2012); Peoples v. Sebring Capital Corp., No. 01 C 5676, 2002 WL 406979, at*8 (N.D. Ill. 2002); Garza v. Swift Transp. Co., Inc., No. 1 CA-CV 07-0472, 2008 WL 3009961, at*7 (Ariz. Ct. App. 2008).

149. Bowers v. Jefferson Pilot Fin. Ins. Co., 219 F.R.D. 578, 581-82 (E.D. Mich. 2016) (concluding that Michigan courts would not apply $§ 211(2)$ ); Berry v. Fed. Kemper Life Assurance Co., 99 P.3d 1166, 1183-84 (N.M. Ct. App. 2004) (holding that $\$ 211$ (2) rule does not "preclude introduction of any evidence concerning specific conversations between insureds and their agents," but also holding that the predominance requirement was satisfied at the class certification stage by application of the reasonable expectations doctrine to the insurance contract at issue). 
generate special benefits. In theory, the uniform construction of an adhesive contract might also have market-based benefits. Scholars have long argued that adhesive contracts allow companies to standardize their relationships with customers in ways that reduce the cost of business, producing savings that in a competitive market might be shared with non-drafters. ${ }^{150}$ To my knowledge, however, no court has recognized those possible benefits as a reason to adopt a uniform construction of an adhesive contract, or to ignore a non-drafting party's actual, reasonable understanding of the transaction.

But courts have suggested uniform construction for the purpose of certifying class actions. And one can understand why. Class actions are not merely efficient means of enforcing adhesive contracts. When individual stakes are low, class adjudication might be the only practicable way to enforce non-drafting parties' contractual rights. ${ }^{151}$ If treating an adhesive contract's terms as the same in every transaction, without regard to individual parties' reasonable understandings, enables the collective adjudication of non-drafter claims, non-drafters on the whole might benefit-even if it is sometimes at the expense of their actual understandings of the deal.

It is worth noting that the decisions in these cases all take place at the class certification stage, before the court is called to interpret the boilerplate language. In one thoroughly reasoned opinion citing section 211(2), the district court confidently affirmed that "[i]f there is any type of standardized agreement that ought to be interpreted uniformly, without regard to the non-drafting party's idiosyncratic comprehension of its terms, it is a consumer checking account agreement." ${ }^{152}$ In order to certify the class, however, the court was not required to determine the meaning of the clause at issue. Nor was it asked to consider any consumer's idiosyncratic comprehension of it. One wonders whether, if called upon to interpret the boilerplate clause in a different case, the court would have ignored evidence proffered by individual consumers that, say, the defendant's agents had represented terms contrary to those in the boilerplate writing. There is an obvious tension between empowering non-drafters to bring class actions through the uniform construction of adhesive boilerplate and the fact that individual non-drafters sometimes reasonably expect something else.

That this tension exists is not to say that it cannot be resolved. Part IV suggested that in insurance law, the doctrines of waiver and estoppel serve to relieve the pressure to consider evidence from individual transactions in the interpretation of policies. Perhaps the misrepresentation doctrine can do the

150. For an early recognition of this point, see Llewellyn's 1939 article, supra note 139, at 701-02. See also, e.g., Carnival Cruise Lines, Inc. v. Shute, 499 U.S. 585, 594 (1991) ("[I]t stands to reason that passengers who purchase tickets containing a forum clause like that at issue in this case benefit in the form of reduced fares reflecting the savings that the cruise line enjoys by limiting the fora in which it may be sued.").

151. See, e.g., Am. Express Co. v. Italian Colors Rest., 570 U.S. 228, 239-53 (2013) (Kagan, J., dissenting); J. Maria Glover, Disappearing Claims and the Erosion of Substantive Law, 124 YALE L.J. 3052 (2015).

152. In re TD Bank, N.A. Debit Card Overdraft Fee Litig., 325 F.R.D. 136, 157 (D.S.C. 2018). 
same in contracts of adhesion. The draft Restatement of the Law of Consumer Contracts, for example, suggests a strong misrepresentation rule for consumer contracts. If a court finds that the business made "a material affirmation of fact or promise that is inconsistent with the standard contract terms," it is empowered to radically reform the adhesive terms or refuse to enforce the contract altogether. ${ }^{153}$ The particularized application of the misrepresentation rule relieves the court from the need to use extrinsic evidence to interpret the adhesive boilerplate. ${ }^{154}$

For present purposes, however, it is enough to observe that recent caselaw on adhesive contracts suggests a very different reason why courts might sometimes construe boilerplate in ways that ignore and are even contrary to the intent of some parties: to facilitate enforcement of contract terms in a class action.

VI

\section{CONCLUSION}

Among the distinctive features of contractual obligations is the fact that they are chosen obligations. The obligations that attach, say, to marrying, to enlisting in the military, or to agreeing to serve as a trustee are defined by law. One might choose to undertake the duty, but one does not choose what the duty is. The obligations that attach to contractual transactions, in distinction, are chosen by the parties themselves. ${ }^{155}$ In a fully negotiated contract, courts therefore look to the parties' intent to determine not only whether the parties agreed to the exchange, but also each party's resulting duties.

Hard boilerplate has always presented a challenge to that classical picture of contract. When the parties employ boilerplate, each presumably agrees to the transaction. But there is a high likelihood that one or both has not read or understood the boilerplate terms to which they have agreed. When courts enforce such boilerplate terms, the parties' contractual obligations might not correspond to the intent of one or both parties. Thus the comparison of the drafting of a standard form or adhesive writing to an act of legislation. ${ }^{156}$

This Article has demonstrated a further and arguably more radical way in which the construction of contractual boilerplate sometimes diverges from the classical picture. Not only might one or both parties to a boilerplate agreement not intend the terms in it-due, say, to a failure to read. One or even both might

153. See Restatement Of THE LAW OF CONSUMER CONTRACTS $\S \S 6,9$ (AM. LAW InST., Tentative Draft, Apr. 18, 2019).

154. The challenges of class certification suggest that it might be suboptimal to exempt business-side communications from the parol evidence rule, as the draft Restatement currently does and I have suggested might be appropriate. See id. $\S \S 7$ (a), 8(c); Klass, supra note 17, at 483-84.

155. See Gregory Klass, What if Fiduciary Duties Are Like Contractual Ones?, in CONTRACT, STATUS, AND FIDUCIARY LAW 93, 108-14 (Paul B. Miller \& Andrew S. Gold eds., 2016) (discussing the relative mutability of fiduciary and contractual obligations).

156. For an extended analysis using the comparison, see generally W. David Slawson, Standard Form Contracts and Democratic Control of Lawmaking Power, 84 HARV. L. REV. 529 (1971). 
manifest an intent contrary to the boilerplate terms, yet nonetheless find themselves bound by those terms for the reason that they appear in boilerplate. Courts sometimes construe mandatory clauses, standard forms, and adhesive writings in ways contrary to the parties' manifest intent precisely because the writing is boilerplate of that type.

This Article has described a number of examples of such boilerplate contrary to party intent, identified the rules that explain those outcomes, and discussed the reasons behind the rules. When the law mandates that boilerplate language be included in certain contractual agreements, the government's understanding of it should, ceteris paribus, control, even if the parties understand it differently. In markets that benefit from uniform contract terms and where a large portion of market participants employ a standard form to achieve those benefits, courts should seek to construe forms uniformly, with limited regard for the intentions of individual users. Courts have at their disposal a number of tools to achieve uniform construction of standard forms. First and foremost, they can defer to the non-binding construction other courts have put on the same language. Depending on the circumstances, they might also restrict their interpretation to the standard form's plain meaning, defer to the form author's interpretation of it, defer to regulators' interpretation of it, or deploy a stringent contra proferentem rule. Application of any of those rules can, in some instances, result in boilerplate terms contrary to some parties' intent. With respect to adhesive contracts, the plain meaning of Second Restatement section 211(2) suggests that it can be reasonable to construe the writing at the expense of non-drafting parties' understandings of it, though the Restatement leaves it unclear just when that is. The section has been applied to hold that adhesive contracts should be construed uniformly to enable class actions seeking to enforce them.

If there is a common thread to these examples of boilerplate contrary to party intent, it is that they demonstrate ways that entering into a contract is a social act. The classical picture depicts the act of contracting as an act of pure choice. Each party arrives at the negotiating table owing no obligations to the other. Each leaves owing just those obligations she has chosen and to which she has agreed to commit herself. This picture is not false. But it represents only part of the whole. As others have observed, contract and status represent ends of a continuum. ${ }^{157}$ Entering into a contract often, to one degree or another, also involves acquiring socially defined obligations - acquiring something like a new status. The various examples of boilerplate contrary to party intent exemplify how sticky those obligations can be.

157. See, e.g., Hanoch Dagan and Elizabeth S Scott, Reinterpreting the Status-Contract Divide: The Case of Fiduciaries, in CONTRACT, STATUS, AND FIDUCIARY LAW 50 (Paul B. Miller \& Andrew S. Gold eds., 2016) (discussing intermediate stations along the spectrum between contract and status). 